\title{
NEW RECORDS OF TWO SOUTHERN FISHES FOUND IN NORTHERN WATERS OF THE IBERIAN PENINSULA
}

\author{
Rafael BAÑÓN ${ }^{1,2 *}$, Alexandre ALONSO-FERNANDEZ ${ }^{1}$, Juan Carlos ARRONTE \\ David BARROS-GARCÍA ${ }^{4}$, and Alejandro DE CARLOS ${ }^{5}$
}

${ }^{1}$ Instituto de Investigaciones Marinas-Consejo Superior de Investigaciones Cientificas, IIM-CSIC,Vigo, Spain

${ }^{2}$ Grupo de Estudos do Medio Mariño (GEMM), Ribeira, Spain

${ }^{3}$ Programa de doctorado en Ingeniería de Costas, Hidrobiología y Gestión de Sistemas Acuáticos, Universidad de Cantabria, Santander, Spain

\author{
${ }^{4}$ Programa de doctorado en Metodología y Aplicaciones en Ciencias de la Vida, Universidade de Vigo, Vigo, Spain \\ ${ }_{5}^{5}$ Departamento de Bioquímica, Xenética e Inmunoloxía, Facultade de Bioloxía, Universidade de Vigo, Vigo, Spain
}

Bañón R., Alonso-Fernandez A., Arronte J.C., Barros-García D., De Carlos A. 2017. New records of two southern fishes found in northern waters of the Iberian Peninsula. Acta Ichthyol. Piscat. 47 (4): 401-405.

\begin{abstract}
The first records of the spearfish remora, Remora brachyptera (Lowe, 1839) (Actinopterygii: Echeneidae), and the white grouper, Epinephelus aeneus (Geoffroy Saint-Hilaire, 1817) (Actinopterygii: Serranidae), from northern Spanish waters are reported. Both findings are, respectively, the second and the first northernmost reports, for both fish species, in the eastern Atlantic. Morphometric and meristic parameters, along with DNA barcoding, confirmed the identification of the remora specimen. Results of the histological examination of the gonads of $R$. brachyptera are also reported, showing a mature male at the developing maturity phase. The grouper specimen was identified taking into account its characteristic coloration based on a photograph.
\end{abstract}

Keywords: NE Atlantic, tropicalisation, morphology, DNA barcoding, fish identification

Two unusual fish species, the spearfish remora, Remora brachyptera (Lowe, 1839) (Actinopterygii: Perciformes: Echeneidae), and the white grouper, Epinephelus aeneus (Geoffroy Saint-Hilaire, 1817) (Actinopterygii: Perciformes: Serranidae), were caught in the north of Spain and are reported herewith for the first time (Fig. 1).

Remora brachyptera is a globally distributed, epipelagic species, found to a maximum depth of $200 \mathrm{~m}$ in tropical to warm temperate seas, frequently associated with billfishes, molids, sharks, and occasionally free swimming (Collette 2010).

Epinephelus aeneus is a demersal, protogynous hermaphrodite and usually solitary species distributed in the eastern Atlantic, along the west coast of Africa down to southern Angola. It is present also in the Mediterranean. Juveniles occur in coastal lagoons and estuaries whereas adults are found on rocky, muddy, and sandy bottoms at depths from 20 to $200 \mathrm{~m}$ (Heemstra and Randall 1993, Heemstra 2016).

A single specimen of $R$. brachyptera of $141 \mathrm{~mm}$ TL (Fig. 2) was captured alive on 7 March 2017 near the coast of Corrubedo (Galicia, NW Spain), at $42^{\circ} 31^{\prime} 13^{\prime \prime} \mathrm{N}$; $09^{\circ} 10^{\prime} 45^{\prime \prime} \mathrm{W}$ by commercial fishers, using gillnets, at $80 \mathrm{~m}$ depth. The specimen was found detached on the deck of the ship after hauling and, therefore, it was not possible to assign it to an associate ('host') species.

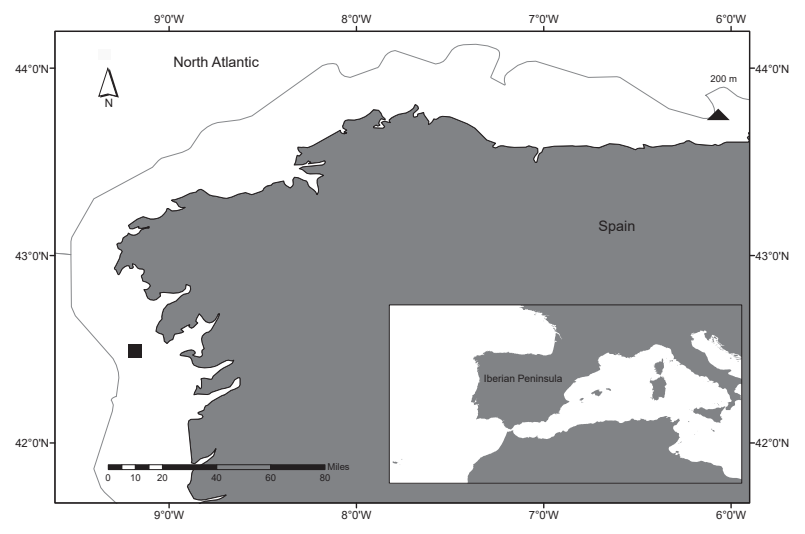

Fig. 1. Sampling locations of Remora brachyptera (square) and Epinephelus aeneus (triangle)

"Correspondence: Dr Rafael Bañón, Instituto de Investigaciones Marinas, Consejo Superior de Investigaciones Científicas, IIM-CSIC, c/Eduardo Cabello 6, 36208 Vigo, Pontevedra, Spain, phone: +34 655220949, e-mail: (RB) anoplogaster@yahoo.es, (AAF) alex@iim.csic.es, (JCA)j_arronte@hotmail.com, (DBG)davbarros@uvigo.es, (ADC) adcarlos@uvigo.es. 
The specimen was preserved alive in the installations of $\mathrm{O}$ Grove Aquarium facility until its death, one month later. Afterwards, the specimen was fixed in $10 \%$ formalin, transferred to $70 \%$ ethanol, and finally deposited in the fish collection of the Museum Luis Iglesias de Ciencias Naturais of Santiago de Compostela (Galicia, Spain) with the reference number MHNUSC 25049.

One specimen of E. aeneus $6.5 \mathrm{~kg}$ in weight (Fig. 2) was caught by a bottom trawler on 24 February 2017 in a fishing ground called Mar del Medio in the Cantabrian Sea (Asturias, North of Spain), at $43^{\circ} 42^{\prime} 44^{\prime \prime} \mathrm{N}$; 006 $04^{\circ} 01^{\prime \prime} \mathrm{W}$ at a depth of $290 \mathrm{~m}$ (Fig. 3). The fish was landed in the port of Gijón and sold at the fish market, which prevented its preservation, but a photograph was taken.

The main morphometric and meristic characters were taken on the $R$. brachyptera specimen following Myoung et al. (2015) (Table 1). The E. aeneus specimen was identified based on the two or three prominent oblique white stripes on the head behind eye characteristic to this species (Heemstra 2016). A muscle sample from fresh $R$. brachyptera specimen was collected and used for DNA purification and sequencing of the standard 5' barcoding region of the mitochondrial COI gene, following previously described procedures (Bañón et al. 2016). PCR amplification was carried out with Thermo Scientific Phire Green Hot Start II PCR Master Mix and the primer set C_FishF1t1-C_FishR1t1 (Ivanova et al. 2007). A 658 nucleotides-long sequence was submitted to the GenBank repository and given the accession number MF038134. In order to explore the taxonomic status of the sample, its sequence was aligned with other phylogeneticallyrelated barcodes using the MEGA6 software (Tamura et al. 2013), and the Neighbor-Joining method (Saitou and Nei 1987) was employed to construct a tree diagram. The divergence among sequences was calculated in the units of the number of base differences per site (p-distances). Confidence limits of this analysis were tested through a bootstrap procedure with 2000 replicates (Felsenstein 1985). The tree was saved as an Enhanced Metafile (emf) and edited using the free and open-source vector graphics editor Inkscape (inkscape.org).

After morphometric measurements were taken, the gonads of $R$. brachyptera were removed and immediately fixed in $10 \%$ formalin buffered with $\mathrm{Na}_{2} \mathrm{HPO}_{4} 2 \mathrm{H}_{2} \mathrm{O}(0.046$ $\mathrm{M}$, molar concentration) and $\mathrm{NaH}_{2} \mathrm{PO}_{4} \mathrm{H}_{2} \mathrm{O}(0.029 \mathrm{M})$. Gonads were dehydrated, embedded in paraffin, sectioned at $3 \mu \mathrm{m}$, and stained with haematoxylin-eosin for histological examination. The specimen was sexed and classified within its correspondent maturity phase using histological criteria (Grier 1981, Brown-Peterson et al. 2011).

Morphological data of Remora brachyptera are consistent with measurements and counts reported by other authors describing this species (Myoung et al. 2015, McEachran and Fechhelm 1998), with minor differences. On the other hand, the molecular identification supports the reliability of the morphological analysis. The resulting
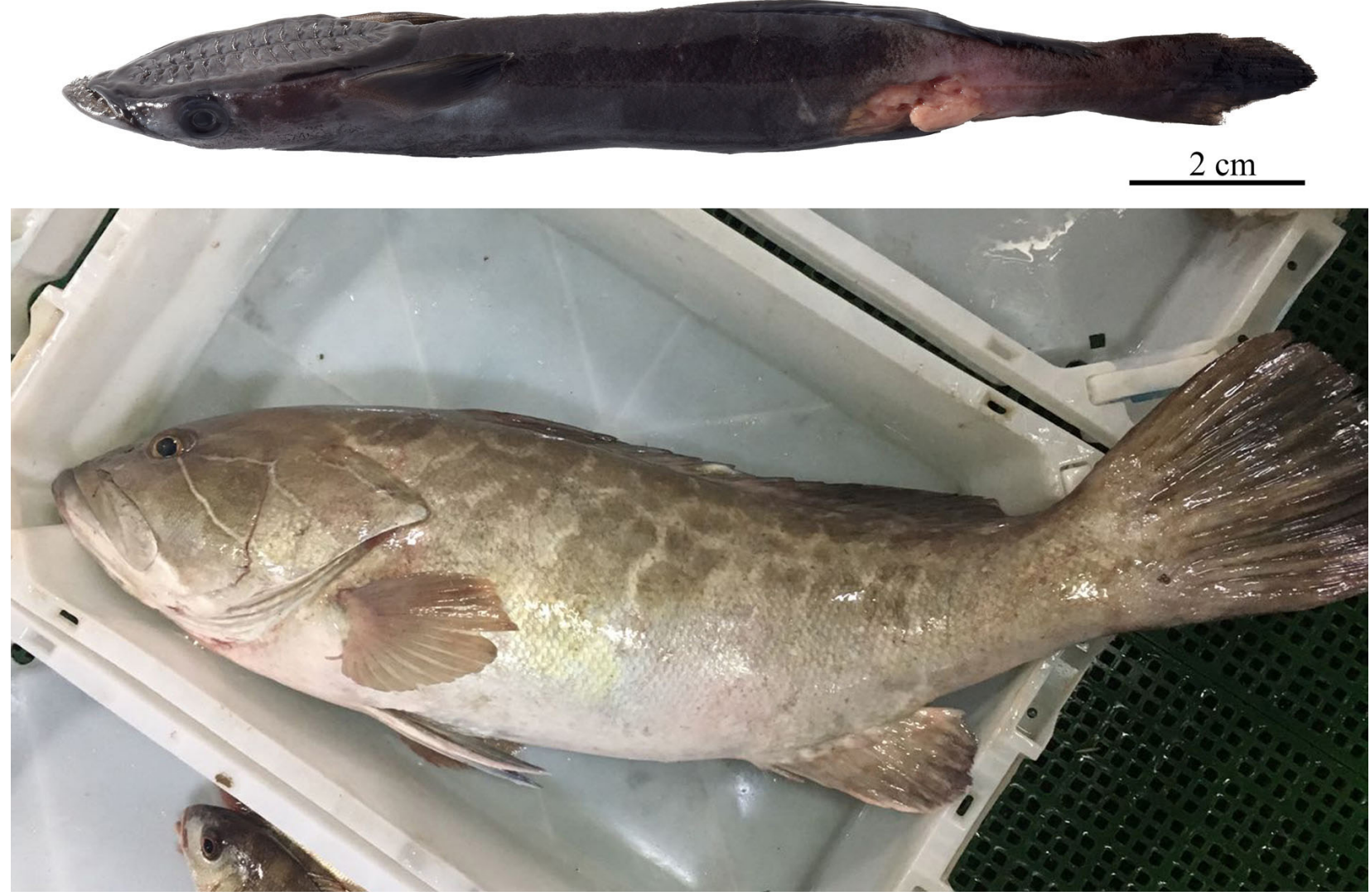

Fig. 2. Specimens caught in northern waters of the Iberian Peninsula: Remora brachyptera caught in Galician waters with a scale bar (top) and Epinephelus aeneus in Asturian waters (bottom) 
Neighbor-Joining tree (Fig. 3) clustered the Galician sequence MF038134 together with other two publicly available barcodes of $R$. brachyptera from Panamá (GU440496) and South Africa (DSLAG581-10) with a mean nucleotide divergence value of $0.41 \%$ among them. This value rose to $15.05 \%$ when the sequence was compared to the ones from the other species included in the alignment, belonging to the family Echeneidae. These figures are concordant with the accepted values described for the respective taxonomic levels in fishes (Ward et al. 2009).

Studies on the reproductive biology are essential for understanding fish population dynamics and histology is an important tool to study routinely basic reproductive parameters (Blazer 2002, Brown-Peterson et al. 2011). Histological examination of the gonads revealed testes with a presence of spermatocysts and spermatids in different development stages evident along lobules. Therefore, the $R$. brachyptera was sexed as a mature male at developing maturity phase. Information about the reproductive biology of $R$. brachyptera is poorly documented. Mature females of this species are reported in the Gulf of Guinea, between July and August, from 11 to $26.5 \mathrm{~cm}$ TL (Pampillón 1996). Our specimen with 14.1 $\mathrm{cm}$ TL falls into this size range, which represents, as far as we know, the first information regarding maturation of males for the species.

Regarding the presence of $R$. brachyptera in Atlantic European waters, Quéro et al. (2003) reported this species from southern Spain and Portugal. Afterwards, Quéro et al. (2007) extended this species northward, to the Bay of Biscay at $43^{\circ} 53^{\prime} \mathrm{N}, 002^{\circ} 07^{\prime} \mathrm{W}$, establishing the northernmost limit in the distribution of this species from the eastern Atlantic. Until now, the presence of
R. brachyptera in northern Spanish Galician waters was doubtful. Solórzano et al. (1988) reported specimens attached to swordfish individuals caught by the Galician pelagic longliners. However, this fleet traditionally operated in Atlantic waters out of Spanish Exclusive Economic Zone, and the exact record location points were unknown. Therefore, the validity of these records was questioned by Bañon et al. (2010). The presently reported discovery confirms the occurrence of this species in Galician waters and establishes the second northernmost record from the eastern Atlantic.

The observed coloration in the specimen of Epinephelus aeneus, mainly the presence of two oblique white stripes on the head behind the eye, considered a diagnostic character (Heemstra 2016), supports, without doubt, its correct identification. An old record of E. aeneus in British waters, reported as 'Perca robusta' by Couch (1832), was subsequently questioned (Heemstra 1991, Heemstra and Randall 1993). Nowadays, the distribution map of the species establishes its northern limit at the latitude of Lisbon, Portugal (Craig 2015). Therefore, we consider the present report as the northernmost confirmed record of this species from the Eastern Atlantic.

The rise in the ocean temperature due to global climate change is causing poleward shifts in the latitudinal abundance and distribution ranges of fish species (Horta e Costa et al. 2014). A rise by $0.24^{\circ} \mathrm{C}$ per decade has been observed in the in the NW Iberian Peninsula since 1974 (Gómez-Gesteira et al. 2011) and a strong warming of $\sim 0.2^{\circ} \mathrm{C}$ per decade for the period $1965-2004$ is apparent from the surface down to the 200-m depth in the Bay of Biscay (Michel et al. 2009).

The occurrence of southern, warm-water fishes has been well documented in the last decades, possibly

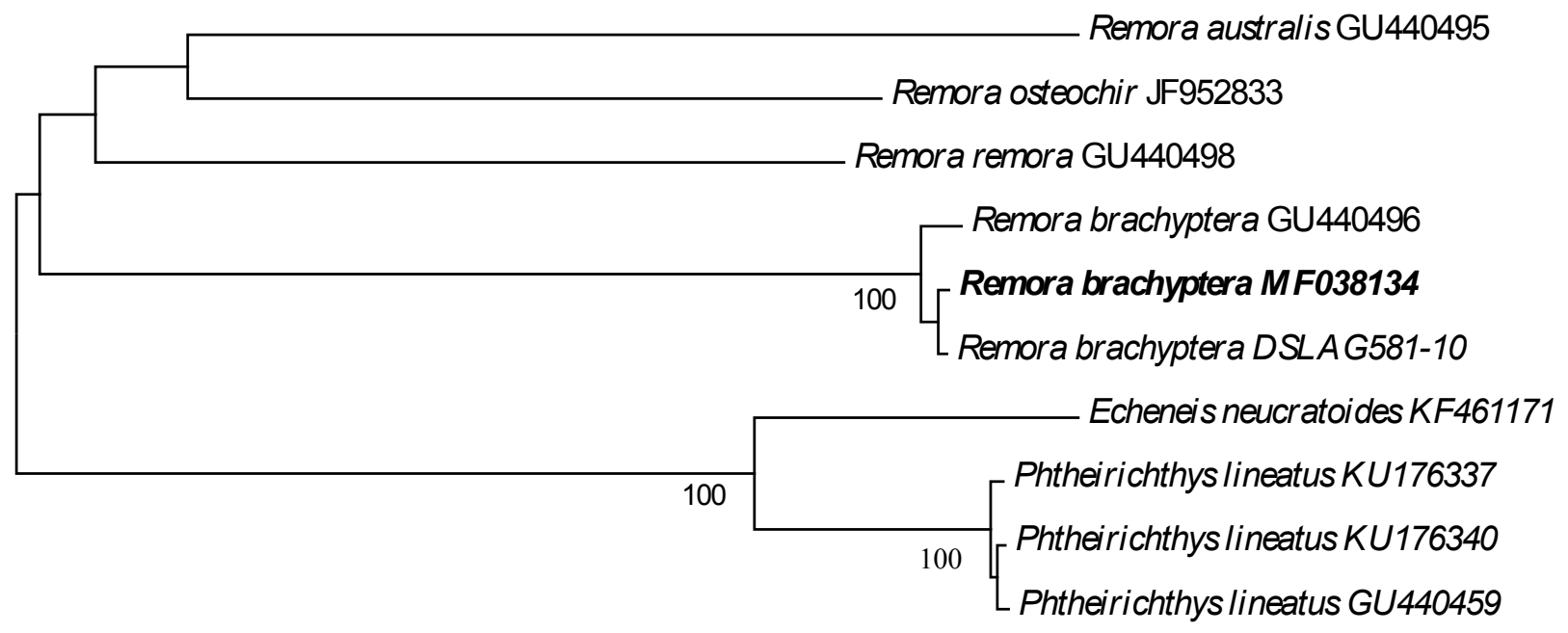

0.02

Fig. 3. Neighbor-Joining tree of the Galician specimen of Remora brachyptera (in bold letters) and related Echeneidae species based on $p$-distances. Numbers at the main nodes are boostrap percentages after 2000 replicates; only values higher than $70 \%$ are shown; the GenBank accession number or BOLD sequence ID accompanies each taxon name; there were a total of 652 nucleotide positions in the final dataset 
Table 1 remora specimen and map, respectively. This study was

Morphometric and meristic characters of the presently described specimen of Remora brachyptera compared with the previously reported values (see Myoung et al. 2015, McEachran and Fechhelm 1998, and Collette 2016)

\begin{tabular}{|c|c|c|c|c|c|}
\hline \multirow[b]{2}{*}{ Character } & \multicolumn{2}{|c|}{ Morphometry } & \multirow[b]{2}{*}{$\begin{array}{l}\text { Meristic } \\
\text { count }\end{array}$} & \multirow[b]{2}{*}{$\begin{array}{l}\text { Weight } \\
{[\mathrm{g}]}\end{array}$} & \multirow{2}{*}{$\begin{array}{c}\text { Previously } \\
\text { reported } \\
\text { values } \\
{[\% \mathrm{SL}]}\end{array}$} \\
\hline & $\begin{array}{c}\text { Absolute } \\
\text { value } \\
\text { [mm] }\end{array}$ & $\% \mathrm{SL}$ & & & \\
\hline Total length (TL) & 141 & & & & \\
\hline Standard length (SL) & 121 & & & & \\
\hline Head length & 30 & 24.8 & & & $24.0-27.7$ \\
\hline Preorbital length & 13 & 10.7 & & & $10.0-13.5$ \\
\hline Eye diameter & 5 & 4.1 & & & $3.2-4.1$ \\
\hline Postorbital length & 12 & 9.9 & & & - \\
\hline Interorbital distance & 14 & 11.6 & & & - \\
\hline Predorsal length & 68 & 56.2 & & & $52.4-62.8$ \\
\hline Dorsal fin base length & 43 & 35.5 & & & $32.5-42.4$ \\
\hline Preanal length & 73 & 60.3 & & & \\
\hline Anal fin base length & 38 & 31.4 & & & $31.5-33.4$ \\
\hline Pectoral length & 18 & 14.9 & & & $11.6-16.0$ \\
\hline Ventral length & 15 & 12.4 & & & $9.8-13.0$ \\
\hline Disc length & 35 & 28.9 & & & $29.4-35.0$ \\
\hline Disc width & 15 & 12.4 & & & $14.9-19.2$ \\
\hline Body depth & 14 & 11.6 & & & $13.9-17.4$ \\
\hline Body width & 10 & 8.3 & & & - \\
\hline No. of dorsal fin rays & & & 28 & & $26-37$ \\
\hline No. of anal fin rays & & & 23 & & $22-34$ \\
\hline No. of pectoral fin rays & & & 22 & & $23-28$ \\
\hline No. of ventral fin rays & & & $\mathrm{I}+5$ & & $\mathrm{I}+5$ \\
\hline No. of disc laminae & & & 16 & & $15-18$ \\
\hline Branchiostegal rays & & & 8 & & 9 \\
\hline Gill rakers & & & $1+11$ & & $10-17$ \\
\hline Total weight $[\mathrm{g}]$ & & & & 13.6 & \\
\hline
\end{tabular}

resembling a tropicalisation process of the North Atlantic Spanish waters ichthyofauna (Bañón et al. 2010). The two species here reported could suppose new cases of this phenomenon, mainly Epinephelus aeneus, a well-known coastal species targeted by the local fisheries, whereas Remora brachyptera is an oceanic non-commercial species less reported in the literature. In fact, a northward displacement of E. aeneus in the Mediterranean Sea was previously observed (Dulčić et al. 2006) and it is suggested that this species is in process of colonisation of new areas in the northern Mediterranean and Adriatic seas (Glamuzina et al. 2000).

\section{ACKNOWLEDGMENTS}

We would like to thank Jose Antonio Crespo (Aquarium de O Grove), for kindly donating the specimen of Remora brachyptera and Jesús Otero Mascato (Technical assistant of confraría de $\mathrm{O}$ Grove) for providing its catch data. We are also grateful to the crew of the F/V Nuevo Bitácora for bringing the Epinephelus aeneus specimen to our attention. Also thanks to Garci and Gonzalo Mucientes (IIM-CSIC) for their assistance with the photo of the carried out due to the collaboration program between CSIC and Xunta de Galicia to analyse fisheries-dependent data from the monitoring program of small-scale fisheries in Galicia (Agreement No. 070401150009).

\section{REFERENCES}

Bañón R., Arronte J.C., Armesto A., Barros-García D., de Carlos A. 2016. Halosaur fishes (Notacanthiformes: Halosauridae) from Atlantic Spanish waters according to integrative taxonomy. Zootaxa 4184 (3): 471-490. DOI: 10.11646/zootaxa.4184.3.3

Bañón R., Villegas-Ríos D., Serrano A., Mucientes G., Arronte J.C. 2010. Marine fishes from Galicia (NW Spain): An updated checklist. Zootaxa 2667: $1-27$. DOI: $10.5281 /$ zenodo. 276366

Blazer V.S. 2002. Histopathological assessment of gonadal tissue in wild fishes. Fish Physiology and Biochemistry 26 (1): 85-101. DOI: $10.1023 / \mathrm{A}: 1023332216713$

Brown-Peterson N.J., Wyanski D.M. Saborido-Rey F., Macewicz B.J., Lowerre-Barbieri S.K. 2011. A standardized terminology for describing reproductive development in fishes. Marine and Coastal Fisheries: Dynamics, Management, and Ecosystem Science 3 (1): $52-70$.

DOI: $10.1080 / 19425120.2011 .555724$

Collette B.B. 2010. Remora brachyptera. The IUCN Red List of Threatened Species 2010: e.T155068A4721000. DOI: 10.2305/IUCN.UK.2010-4.RLTS.T155068A4721000.en

Collette B.B. 2016. Echeneidae. Pp. 2441-2443. In: Carpenter K.E., De Angelis N. (eds.) The living marine resources of the Eastern Central Atlantic. Bony fishes part 2 (Perciformes to Tetradontiformes) and Sea turtles. FAO Species Identification Guide for Fishery Purposes. Volume 4. FAO, Rome.

Couch J. 1832. [Art. IV.] Fishes new to the British fauna, contained in Couch's "History of the fishes of Cornwall". Magazine of Natural History and Journal of Zoology, Botany, Mineralogy, Geology, and Meteorology 5: 15-24.

Craig M.T. 2015. Epinephelus aeneus. The IUCN Red List of Threatened Species 2015: e.T132722A44902814. Downloaded on 19 May 2017.

Dulčić J., Tutman P., Ćaleta M. 2006. Northernmost occurrence of the white grouper, Epinephelus aeneus (Perciformes: Serranidae), in the Mediterranean area. Acta Ichthyologica et Piscatoria 36 (1): 73-75.

DOI: 10.3750/AIP2006.36.1.10

Felsenstein J. 1985. Confidence limits on phylogenies: An approach using the bootstrap. Evolution 39 (4): 783-791.

DOI: $10.2307 / 2408678$

Glamuzina B., Tutman P., Geffen A.J., Kožul V., Skaramuca B. 2000. First record of white grouper, Epinephelus aeneus (Serranidae) in the south eastern Adriatic. Cybium 24 (3): 306-308. 
Gómez-Gesteira M., Gimeno L., de Castro M., Lorenzo M.N., Alvarez I., Nieto R., Taboada J.J., Crespo A.J.C., Ramos A.M., Iglesias I., Gómez-Gesteira J.L., Santo F.E., Barriopedro D., Trigo I.F. 2011. The state of climate in NW Iberia. Climate Research 48 (2-3): 109-144. DOI: $10.3354 / \mathrm{cr} 00967$

Grier H.J. 1981. Cellular organization of the testis and spermatogenesis in fishes. American Zoologist 21 (2): 345-357.

Heemstra P.C. 1991. A taxonomic revision of the eastern Atlantic groupers (Pisces: Serranidae). Boletim do Museu Municipal do Funchal 43 (226): 5-71.

Heemstra P.C. 2016. Serranidae. Pp: 2365-2413. In: Carpenter K.E., De Angelis N. (eds.) The living marine resources of the Eastern Central Atlantic. Bony fishes part 2 (Perciformes to Tetradontiformes) and Sea turtles. FAO Species Identification Guide for Fishery Purposes. Volume 4. FAO, Rome.

Heemstra P.C., Randall J.E. 1993. FAO species catalogue Vol. 16. Groupers of the world (family Serranidae, subfamily Epinephelinae): An annotated and illustrated catalogue of the grouper, rockcod, hind, coral grouper, and lyretail species known to date. FAO, Rome.

Horta e Costa B., Assis J., Franco G., Erzini K., Henriques M., Gonçalves E.J., Caselle J.E. 2014. Tropicalization of fish assemblages at temperate biogeographic transition zones. Marine Ecology Progress Series 504: 241-252.

DOI: $10.3354 / \operatorname{meps} 10749$

Ivanova N.V., Zemlak T.S., Hanner R.H., Hebert P.D.N. 2007. Universal primer cocktails for fish DNA barcoding. Molecular Ecology Notes 7 (4): 544-548. DOI: $10.1111 / \mathrm{j} .1471-8286.2007 .01748 . \mathrm{x}$

McEachran J.D., Fechhelm J.D. 1998. Fishes of the Gulf of Mexico. Scorpaeniformes to Tetraodontiformes. Vol. 2. University of Texas Press, Austin, TX, USA.

Michel S., Vandermeirsch F., Lorance P. 2009. Evolution of upper layer temperature in the Bay of Biscay during the last 40 years. Aquatic Living Resources 22 (4): $447-461$.
DOI: $10.1051 / \mathrm{alr} / 2009054$

Myoung S.H., Myoung J.-G., Kim J.-K. 2015. New Records of Remora brachyptera and R. osteochir (Perciformes: Echeneidae) from Korea. Animal Systematics, Evolution and Diversity 31 (2): 101-106. DOI: 10.5635/ASED.2015.31.2.101

Pampillón J.C. 1996. Rémoras (Pisces Echeneididae) del golfo de Guinea: especificidad por sus hospedadores y estudio de algunos parámetros biológicos. Boletín Instituto Español de Oceanografía 12 (1): 31-42.

Quéro J.-C., Porche P., Vayne J.J. 2003. Guide des poissons de l'Atlantique européen. Delachaux et Niestlé, Paris, France.

Quéro J.-C., Spitz J., Vayne J.J., Abernot-Le Gac C., De Casamajor M.N., Duhamel E., Morandeau G., Gautier G., Van Canneyt O. 2007. Observations ichtyologiques effectuées en 2006. Annales de la Société des sciences naturelles de la CharenteMaritime 9 (7): 699-707.

Saitou N., Nei M. 1987. The neighbor-joining method: A new method for reconstructing phylogenetic trees. Molecular Biology and Evolution 4 (4): 406-425. DOI: 10.1093/oxfordjournals.molbev.a040454

Solórzano M.R., Rodríguez J.L., Iglesias J., Pereiro F.X., Álvarez F. 1988. Inventario dos peixes do litoral galego (Pisces: Cyclostomata, Chondrichthyes, Osteichthyes). [Inventory of Galician coastal fishes (Pisces: Cyclostomata, Chondrichthyes, Osteichthyes).] Cadernos da Área de Ciencias Biolóxicas (Ediciós do Castro). Inventarios; Vol. 4. Seminario de Estudos Galegos. [In Galician.]

Tamura K., Stecher G., Peterson D., Filipski A., Kumar S. 2013. MEGA6: molecular evolutionary analysis version 6.0. Molecular Biology and Evolution 30 (12): 2725-2729.

DOI: $10.1093 / \mathrm{molbev} / \mathrm{mst} 197$

Ward R.D., Hanner R., Hebert P.D.N. 2009. The campaign to DNA barcode all fishes, FISHBOL. Journal of Fish Biology 74 (2): 329-356.

DOI: $10.1111 /$ j.1095-8649.2008.02080.x

Received: 25 May 2017

Accepted: 13 September 2017

Published electronically: 31 December 2017 